\title{
ANALISIS PEMBIAYAAN AR-RAHN UNTUK USAHA MIKRO (ARRUM) PADAPT. PEGADAIAN SYARIAH (PERSERO) CABANG BLAURAN SURABAYA
}

\author{
Eva Ervina \& Abdul Wahab \\ evaervina@gmail.com
}

\begin{abstract}
Abstrak
Rumusan masalah dalam penelitian ini dapat dirumuskan sebagaimana berikut: Pertama, bagaimanakah strategi pemasaran pembiayaan Arrum pada produk PT. Pegadaian Syariah (persero) Cabang Blauran Surabaya? Kedua, bagaimanakah analisis pembiayaan Arrum pada PT. Pegadaian Syariah (persero) Cabang Blauran Surabaya? Ketiga, apakah pembiayaan Arrum pada PT. Pegadaian Syariah (persero) sudah sesuai dengan hukum ekonomi syariah? Penelitian ini bertujuan untuk lebih mendalami segala aspek kehidupan, disamping itu juga merupakan sarana untuk mengembangkan ilmu pengetahuan, baik dari segi teoritis dan praktis.

Penelitian ini bersifat fenomenologi dengan deskripsi-analisis, yaitu menggambarkan bagaimana analisis terhadap pembiayaan Arrum di PT. Pegadaian Syariah (Persero)Cabang Blauran. Setelah data dikumpulkan kemudian diolah dan dianalisa dengan analisa kualitatif dengan logika induktif.

Dari penelitian yang telah dilakukan, dapat ditarik kesimpulan: pertama, strategi yang digunakan dalam pemasaran pembiayaan pada PT. Pegadaian Syariah Kantor Cabang Blauran yaitu Produk,distribusi, promosi, dan harga serta sudah diaturdalamPedoman OprasionalGadaiSyariah yang berlaku umum, tetapi tergantung cabang yang berbeda-beda. Kedua, mekanisme pembiayaan Ar-Rum adalah mudah dengan persyaratan yang tidak rumit. Ketiga, pembiayaan Ar-Rum sudah berjalan sesuai dengan Fatwa Dewan Islam NasionalNo. 25/DSNMUI/III/2002 Tanggal 26 Juni 2002.

Harapannya dari penelitian ini kedepannya Pegadaian perlu mensosialisasikan produk-produk yang ditawarkan oleh Pegadaian Syariah. Khususnya pada produk pembiayaan Arrum serta pihak Pegadaian Syariah agar tetap mempertahankan keramahan dalam pelayanan, bahkan perlu ditingkatkan agar nasabah merasa nyaman dan senang atas pelayanan yang diberikan oleh pegadaian.
\end{abstract}

Kata Kunci: Perbankan syariah, rahn dan usaha mikro.

\section{A. PENDAhuluan}

Perbedaan antara lembaga keuangan bank dengan lembaga keuangan bukan bank, yaitu lembaga keuangan bank merupakan lembaga keuangan yang paling lengkap kegiatannya, yaitu menghimpun dana ke masyarakat dan menyalurkan kembali dana tersebut dalam bentuk pinjaman serta melaksanakan kegiatan jasa keuangan lainnya, sedangkan lembaga keuangan bukan 
bank kegiatannya difokuskan pada salah satu kegiatan keuangan saja.

Untuk mengatasi kesulitan dana, dimana dana yang dibutuhkan dapat dipenuhi tanpa menjual barang-barang berharga, maka masyarakat dapat menjaminkan barang-barang ke lembaga tertentu dengan syarat tertentu yaitu syarat Inbezitstelling dimana barang jaminan harus dibawa keluar dari kekuasaan pemilik barang. ${ }^{1}$ Barang yang dijaminkan tersebut pada waktu tertentu dapat ditembus kembali setelah masyarakat melunasi pinjamannya. Kegiatan meminjamkan barang-barang bergerak untuk memperoleh sejumlah uang dan dapat dilunasi kembali setelah jangka waktu tertentu tersebut dengan nama usaha gadai. Kredit tidak lepas hubungan dari lembaga jaminan. Lembaga jaminan timbul karena dua hal yaitu karena Undang-Undang dan karena perjanjian. Salah satu lembaga jaminan yang timbul karena perjanjian adalah pegadaian.

Usaha gadai adalah kegiatan menjaminkan barang-barang berharga kepada pihak tertentu, guna untuk memperoleh sejumlah uang dan barang yang dijaminkan akan ditebus kembali sesuai dengan perjanjian antara nasabah dengan lembaga gadai. ${ }^{2}$

Seiring dengan kemajuan zaman dan tuntutan masyarakat Muslim di Indonesia yang sangat merindukan bertransaksi berdasarkan

\footnotetext{
${ }^{1} \mathrm{~S}$, Burhanuddin, Aspek Hukum Lembaga Keuangan Syariah, (Yogyakarta: Graha Ilmu, 2010), 170.

${ }^{2}$ Kasmir, Bank dan Lembaga Keuangan Lainnya, (Jakarta: Rajawali Press, 2008), 262.
}

prinsip-prinsip Islam dalam berbagai aspek termasuk di bidang Pegadaian, kemudian Pemerintah mengeluarkan Undang-undang Nomor 10 tahun 1998, Perubahan atas Undangundang Nomor 7 tahun 1992 Tentang Perbankan, Undang-undang memberikan peluang untuk diterapkan praktek perekonomian sesuai Syariah dibawah perlindungan hukum positif, sebagaimana termuat pada pasal 1 ayat 12 dan 13: Pembiayaan berdasarkan prinsip Syariah adalah penyediaan uang atau tagihan yang dipersamakan dengan itu berdasarkan persetujuan atau kesepakatan antara Bank dengan pihak lain yang mewajibkan pihak yang dibiayai untuk mengembalikan uang atau tagihan tersebut setelah jangka waktu tertentu dengan dengan imbalan atau bagi hasil. ${ }^{3}$

Pegadaian Syariah masih menggunakan kebijakan gadai konvensional, disisi lain harus menerapkan prinsip-prinsip syariah, dan pengawasannya secara kolektif dari pusat, hal yang demikian itulah yang menarik untuk dikaji dan dievaluasi secara kritis.

Lembaga tersebut mengklaim dirinya mengatasi masalah tanpa masalah, apakah hal itu betul atau justru tidak mengatasi masalah tetapi membuat masalah.

Pada zaman sekarang ini banyak bermunculan lembaga keuangan baik bank atau bukan bank yang yang mengklaim dirinya sebagai lembaga keuangan Syariah dan banyak juga yang hanya kulitnya saja tapi prakteknya tidak Syariah.

\footnotetext{
${ }^{3}$ www.hukumonline.com/pusatdata/downloa dfile/lt4cce89fb14e43/parent/334, 24 Agustus 2018.
} 
Perum Pegadaian Syariah Cabang Blauran yang terletak di Jalan Blauran No.74-76, Surabaya berdiri pada tanggal 1 April 2006 dan mulai efektif bekerja melayani gadai yang sesuai Syariah, sampai sekarang sudah berusia lebih kurang sepuluh tahun, perkembangan gadai syariah tersebut tidak sepesat Perbankan Syariah yang memang diminati banyak nasabah kelas menengah keatas, karena kesan gadai adalah hanya diminati oleh masyarakat kelas bawah yang bersifat konsumtif, hal ini terlihat dari produk yang ditawarkan oleh gadai Syariah Blauran belum banyak karena peminatnya masih relatif didominasi oleh kalangan bawah yang dengan terpaksa lari ke Pegadaian karena kebutuhan yang mendesak, hal ini penulis ketahui ketika berada di Pegadaian dan mencoba wawancara dengan nasabah yang datang di Pegadaian Syariah. Berdasarkan klaim Perum Pegadaian dan uraian tersebut diatas Penulis tertarik untuk meneliti dan mengevaluasi tentang Implementasi akad ijarah (Sewa-Menyewa) pada Pegadaian Syariah Cabang Blauran, Surabaya.

Metode penelitian adalah suatu cara untuk mengerjakan sesuatu yang sistematis, dan metodologi adalah ilmu pengetahuan yang mempelajari proses berfikir, analisa berfikir serta mengambil kesimpulan yang tepat dalam suatu penelitian. ${ }^{4}$ Dengan demikian, dalam penulisan ini juga digunakan metode tertentu yang sesuai pokok masalah yang dibahas erat agar dapat

${ }^{4}$ Soerjono Soekanto, Penelitian Hukum Normatif Suatu Tinjauan Singkat, (Jakarta: Raja Grafindo Persada, 2001), 3. menghasilkan data-data yang bisa dibuktikan kebenarannya. Adapun metode yang digunakan dalam penulisan ini adalah.

Penelitian lapangan (field research) yang merupakan penelitian secara rinci satu subjek tunggal, satu kumpulan dokumen atau satu kejadian tertentu.Penelitian ini bersifat deskriptif analitis, maksudnya memaparkan data-data yang ditemukan di lapangan dan menganalisisnya untuk mendapatkan kesimpulan yang benar dan akurat. $^{5}$ Selain itu juga menerapkan penelitian hukum empiris, yaitu penelitian hukum yang dilakukan dengan cara meneliti prilaku hukum masyarakat atau pelaksanaan peraturan hukum dalam praktik (law in action).

Dengan tipe penelitian hukum normatif, penulis meneliti bahan kepustakaan khususnya yang berkaitan dengan akad ijarah, sebagai pendukung untuk meneliti peraturan Akad ijarah sebagaimana diatur dalam Fatwa DSN mengenai Pembiayaan Ijarah No. 09/DSNMUI/IV/2000. Sedang dengan tipe penelitian hukum empiris, penulis meneliti pelaksanaan Pembiayaan Arrum yang terjadi dalam praktik di PT. Pegadaian Syariah (Persero) Cabang Blauran, Surabaya dihubungkan dengan Fatwa DSN mengenai Pembiayaan Ijarah No. 09/DSN-MUI/IV/2000 tersebut.

Disamping itu, penulis juga melakukan penelitian yang berorentasi pada perubahan (reform oriented research), yaitu penelitian yang secara intensif mengevaluasi

${ }^{5}$ Cholid Narbuko dan Abu Achmadi, Metodologi Penelitian, cet. VI, (Jakarta: Bumi Aksara, 2005), 4. 
pemenuhan ketentuan yang sedang berlaku dan merekomendasikan perubahan terhadap peraturan manapun yang dibutuhkan. ${ }^{6} \mathrm{Hal}$ ini karena dalam penelitian ini setelah penulis meneliti pelaksanaan akad ijarah secara mendalam sebagai implementasi Fatwa DSN mengenai Pembiayaan Ijarah No. 09/DSNMUI/IV/2000, penulis merekomendasikan beberapa hal demi terlaksanakannya akad ijarah secara optimal dengan hasil yang optimal juga.

Data Primer merupakan data yang diperoleh langsung dari informan penelitian, berupa hasil wawancara, data primer akan menjadi sumber data utama dalam penelitian.

Data Sekunder merupakan data yang mendukung data primer. Data yang ditambahkan atau pelengkap yang bisa didapat dari studi pustaka dan literatur-literatur yang berkaitan dengan penelitian.Data sekunder diperoleh melalui bahan hukum primer, bahan hukum sekunder dan bahan hukum tersier $^{7}$.

Setelah data dikumpulkan kemudian diolah dan dianalisa dengan analisa kualitatif dengan logika induktif. ${ }^{8}$ Pola berpikir induktif ini untuk menganalisis datadata yang bersifat khusus untuk

${ }^{6}$ Hutchinson, dalam Granita Ramadhani, Metodologi Penelitian Hukum, (Jakarta: FHUI, 2000), 56-57.

${ }^{7}$ Soerjono Soekanto dan Sri Mamudji, Penelitian Hukum Normatif, Suatu Tinjauan Singkat, (Jakarta: Rajawali, 2010), 15

${ }^{8}$ Soeharti Sigit, Pengantar Metodologi Penelitian Sosial, Bisnis-Manajement, (Jakarta: Bumi Aksara, 1999), 155 ditarik kepada yang umum. Kemudian dari hasil analisa data yang diperoleh dideskripsikan secara urut dan teliti sesuai dengan permasalahan yang dikaji.

Analisis kualitatif secara deskriptif dipergunakan untuk menggambarkan dan menganalisis realitas pelaksanaan pembiayaan Arrum di PT. Pegadaian Syariah (Persero) Cabang Blauran, Surabaya dihubungkan dengan peraturan perundang-undangan yang terkait dengan akad ijarah, khususnya akad ijarah.

Sedang analisis kualitatif secara perspektif dipergunakan untuk menganalisis beberapa alternatif yang harus ditempuh untuk mengoptimalkan pelaksanaan akad ijarah di PT. Pegadaian Syariah (Persero) Cabang Blauran, Surabaya.

\section{B. HASIL PENELITIAN DAN PEMBAHASAN \\ 1. Pegadaian sebagai Lembaga Keuanagan Bisnis}

Pegadaian Syariah sebagai lembaga keuangan bisnis, selain menawarkanpembiayaan Ar-Rum untuk Usaha Mikro Kecil, Pegadaian Syariah jugamenawarkan layanan jasa berupa: ${ }^{9}$

a. Pemberian pinjaman atau pembiayaan atas dasar hukum gadai syariah. Produk inimensyaratkan pemberian pinjaman dengan penyerahan barang sebagai jaminan. Barang gadai harus berbentuk barang bergerak, oleh karena itu pemberian pinjaman sangat ditentukan olehnilai dan jumlahdari barang yang digadaikan.

${ }^{9}$ Zainuddin Ali, Hukum Gadai Syariah, (Jakarta: Sinar Grafika, 2008), 53. 
b. Penaksiran nilai barang, yaitu pegadaian syariah memberikan jasa penaksiran atas nilai suatu barang yang dilakukan oleh calon nasabah. Demikian juga orang yang hanya bermaksud menguji kualitas barang yang dimilikinya saja dan tidak hendak menggadaikan barangnya itu. Jasa ini diberikan karena pegadaian Syariah mempunyai alat penaksir yang keakuratanya dapat diandalkan. Demikian juga dengan sumber insani yang berpengalaman dalam menaksir. Untuk jasa penaksiran dimaksud, hanya memungut ongkos biaya penaksiran.

c. Penitipan barang, Pegadaian syariah juga menerima titipan barang dari masyarakat berupa surat-surat berharga seperti sertifikat tanah, ijasah, motor. Fasilitas ini diberikan bagi mereka yang ingin melakukan perjalanan jauh dalam waktu yang relatif lama atau karena penyimpanan di rumah dirasakan kurang aman. Atas jasa penitipan tersebut, pegadaian syariah dapat memungut ongkos penyimpanan.

d. Gold counter, yaitu jasa penyediaan fasilitas berupatempat penjualan emas yang terjamin kualitas dan keasliannnya. Gold counter ini semacam toko dengan emas galeri 24, di mana setiap pembelian emas di toko milik pegadaian syariah akan dilampirkan sertifikat jaminan. Dengan sertifikat tersebut masyarakat percaya dan yakin akan kualitas dan keaslian emas.

\section{Mekanisme}

Operasional Pembiayaan Ar-Rum pada PT. Pegadaian Syariah (Persero) Cabang Blauran,
Surabaya

Pegadaian Syariah terus berkomitmen mengembangkan produk-produk jasa keuangan yang dibutuhkan masyarakat. Salahsatunya adalah produk Ar-Rahn untukUsaha Mikro, atau biasa disebut Ar-Rum. Produk Ar-Rum merupakan skim pembiayaan berbasis syariah bagi para pengusaha mikro kecil untuk keperluan usaha yang didasarkan atas kelayakan usaha. Pembiayaan diberikan dalam jangka waktu tertentu dengan pengembalian pinjaman dilakukan dengan cara angsuran dan hanyadi peruntukan bagipengusaha mikro.

Mekanisme

Operasional penyaluran dana pembiayaan ArRum pada Pegadaian Syariah yaitu: ${ }^{10}$ a. Pihak Pegadaian menerima berkas nasabah yang akan mendapatkan pembiayaan Ar-Rum dengan melampirkan FotoCopy Kartu Keluarga (KK), FotoCopy KTP Suami/Istri, FotoCopy Surat Nikah, surat keterangan usaha dan telah berjalan minimal 1 tahun, BPKB Kendaraan bermotor, fotocopy STK, FotoCopy rekeningtabungan, FotoCopy pembayaran listrik dan telepon, FotoCopy pembayaran PBB.

b. Mengisi formulir aplikasi pembiayaan AR-RUM.

$$
\text { c. Petugas Pegadaian }
$$

memeriksa keabsahan dokumendokumen yang dilampirkan oleh nasabah dan melakukan survey analisis kelayakan usaha serta menaksir agunan. Setelah memenuhi syarat-syarat yang diajukan oleh

\footnotetext{
${ }^{10}$ Wuwuh A, Wawancara, Surabaya: 20 Juli 2018.
} 
pihak Pegadaian, selanjutnya nasabah menandatangani akad pembiayaan Ar-Rum yang diketahui suami/istri.

Keunggulan Produk Ar-Rum pada Pegadaian Syariah:

a. Persyaratan yang mudah, proses yang cepat kurang lebih tiga hari, serta biaya biaya yang kompetitif dan relatif murah.

b. Jangka waktu pembiayaan yang fleksibel mulai dari 12 bulan, 18 bulan, 24 bulan, hingga 36 bulan.

c. Nilai pembiayaan dapat mencapai hingga $70 \%$ dari nilai taksiran agunan.

d. Pelunasan dilakukan secara angsuran tiap bulan dengan angsuran tetap.

e. Pelunasan sekaligus dapat dilakukan sewaktu-waktu dengan pemberian diskon ijarah.

f. Didukung oleh staf berpengalaman serta ramah dan santun dalam memberikan pelayanan.

Persyaratan-persyaratan

untuk Memperoleh Pembiayaan ArRum pada Pegadaian Syariah: ${ }^{11}$

a. Calon rahin atau nasabah merupakan pengusaha mikro yang memiliki usaha yang produktif dan mempunyai barang berupa kendaraan bermotor sebagai objek jaminan pinjaman.

b. Calon rahin tidak menjadi nasabah kredit Kreasi dicabang pengadian konvensional dan tidak menjadi rahin Ar-Rum di cabang Pegadaian Syariah lainnya.

${ }^{11}$ Andri Soemitra, Bank dan Lembaga Keuangan Syariah, (Jakarta: Kencana, 2010), 401 c. Calon rahin bukan dari petugas pengelolah Ar-Rum itu sendiri.

d. Identitas calon rahin yang jelas.

Indonesia.

e. Warga Negara

f. Memiliki tempat tinggal yang tetap.

g. Status usaha rahin adalah usaha perorangan atau badan hukum yang menjalankan usahanya sah menurutUndang-Undang Republik Indonesia.

h. Usia usahanya lebih dari 1 tahun.

i. Jenis usahanya tidak termaksud yang dilarang diberikan pinjaman.

j. Tempat usahanya tidak terlarang dan tidak menimbulkan gangguan terhadap lingkungan masyarakat.

k. Menyerahkan foto copy AD/ART atau akte pendirian badan usaha dengan menunjukkan aslinya.

1. Menyerahkan

SIUP/SITU/ atau izin usaha lainnya dengan menunjukkan aslinya.

Objek Jaminan Pembiayaan Ar-Rum (Marhun)

a. Kendaraan bermotor adalah milik sendiri yang dibuktikan dengan nama yang tertera di BPKB dan STNK sama dengan yang tertera di KTP.

milik pribadi maka harus menyertakan persetujuan menjaminkan kendaraan dari pemilik.

c. Jenis dan merk kendaraan merupakan jenis dan merk yang sudah dikenal dan umum 
digunakan masyarakat serta pemasarannya tidak sulit.

d. Sistem dan prosedur menaksir sesuai dangan prosedur yang berlaku diperusahaan.

e. Sebagai tindakan antisipasi terhadap penyalahgunaan $\mathrm{BPKB}$, maka setelah proses piutang disepakati, agar dilakukan proses pemblokiran BPKB atas biaya rahin.

f. Satu perjanjian hutang piutang Ar-Rum diperbolehkan didukung sampai dengan 3 jenis marhun.

g. Khusus kendaraan bermotor baik roda empat atau lebih dengan menggunakan plat polisi kuning, harus melengkapi persyaratan serta harus melengkapi isin trayek dan buku Kir dari dinas lalu lintas dan angkutan jalan raya.

Jangka waktu pembiayaan yang ditetapkan oleh perusahaan minimal 12 bulandan maksimal 36 bulan dengan pengembalian pembiayaan dilakukan dengan caraangsuran tiap bulannya, sedangkan akad yang digunakan pada Ar-Rum ini adalahIjarah.

Pembayaran angsuran bulanan dilakukan di kantor Cabang Pegadaian Syariah penyelengara pembiayaan Ar-Rum melalui petugas yang ditunjuk. Batas akhir tanggal pembayaran angsuran ditentukan berdasarkan tanggal transaksi (pencairan pembiayaan) dengan ketentuan sebagai berikut:

a. Tanggal 10 bulan berikutnya untuk tanggal 1 s.d 10

b. Tanggal 20 bulan berikutnya untuk transaksi tanggal 11 s.d 20

c. Tanggal 30/31 bulan berikutnya untuk transaksi tanggal
21 s.d 31 (bulan februaripada akhir bulan).

Pembiayaan angsuran lebih cepat dari tanggal angsuran dapat diterima tanpa mengurangi jumlah angsuran. Apabila tanggal angsuran bertepatan pada hari libur maka pembayarannya dapat dilakukan pada hari kerja berikutnya.

\section{Analisis Strategi} Pemasaran Pembiayaan Ar-Rum pada PT. Pegadaian Syariah (Persero) Cabang Blauran, Surabaya

Untuk mencapai sasaran yang sudah ditentukan strategi pemasaran yang telah dilakukan oleh Pegadaian Syariah meliputi 4 variabel dalam bauran pemasaran, yaitu:

1. Strategi dalam Bidang Produk Ar-Rum

Ar-Rum merupakan hasil pengembangan produk (Ar-Rahn untuk usaha mikro kecil). Ar-Rum adalah skim pembiayaan berprinsip syariah Islam bagi para pengusaha mikro untuk keperluan pengembangan usaha dennagan sistem pengembalian secara angsur tiap bulan dengan jumlah tetap, namun pelunasan sekaligus juga dapat dilakukan sewaktu-waktu denagan pemberian diskon ijaroh dan jaminan atau angunan berupa BPKB kendaraan bermotor (mobil atau motor).

Tujuan Ar-Rum dari Pegadaian Syariah sendiri memiliki maksud untuk pengembangan usaha mikro dan kecil yang membutuhkan pembiayaan modal kerja atau investasi secara syariah.

2. Strategi dalam Bidang Harga 
Harga yang ditawarkan pada sektor jasa sangat memiliki kompleksitas yang lebih ketimbang pada sektor barang, ini dikarnakan pada penciptaan margin laba pada sector jasa yang terlihat sederhana namun memiliki tingkat pertimbangan margin yang membutuhkan kematangan kebijakan yang tepat. Pada dasarnya harga akan sangat mempengaruhi persepsi dan dan permintaan oleh nasabah maupun pencapaian target dan penawaran oleh perusahaan, sehingga dalam menentukan harga jual ada beberapa tujuan yang ingin dicapai antara lain:

maksimum

a. Mendapatkan laba

b. Pencapaian

target pengembalian

investasi

$$
\text { c. Mempertahan }
$$

\section{kan market share}

Penetapan strategi harga produk gadai syariah pada Pegadaian Syariah dengan cara memotong tarif ijarah, apabila pinjaman pegadaian yang diperoleh nasabah tidak mencapai batas maksimum prosentase peminjaman (yakni 80\%). Dari harga kendaraan /taksiran barang jaminan, maka kepada nasabah tersebut akan diberikan diskon ijaroh yang besarnya akan ditetapkan sesuai dengan uang pinjaman.

3. Strategi dalam Bidang Distribusi

Mengenai saluran distribusi Pegadaian Syariah telah membuka UPC (Unit Pelayanan Cabang) kecil agar mudah dijangkau oleh nasabah yang membutuhkan dana cepat untuk kebutuhan produktif maupun konsumtif.

Strategi distribusi yang dilakukan oleh Pegadaian Syariah adalah dengan membuka UPC-UPC kecil yang mudah dijangkau oleh nasabah yang membutuhkan dana cepat. UPC-UPC tersebut dibangun di tempat-tempat dekat dengan pasar, permukiman dan jalan-jalan besar yang mudah dijangkau oleh nasabah dan perumahan yang mayoritas memiliki usaha. Salah satunya adalah Pegadaian Syariah Cabang Blauran.

Dalam strategi distribusi ini tidak ada kerja sama yang dilakukan oleh Pegadaian Syariah dengan Bank Mandiri. Kerjasama yang dilakukan dengan Bank Syariah Mandiri hanya sebagai penambah modal awal. Saat ini Pegadaian Syariah menggunakan modal sendiri. Strategi ini juga ampuh dalam menarik minat nasabah.

Promosi

4. Strategi dalam Bidang

Promosi yang dilakukan oleh

Pegadaian Syariah dalam memasarkan produk gadai syariah adalah dengan cara:

a. Kantor Pusat PERUM Pegadaian (KPPP), melalui lembaga elektronik seperti tv, radio, surat kabar dan lain-lain yang sifatnya mencakup wilayah seluruh Indonesia dan dalam bentuk kata-kata atau gambar yang tertuang dalam buku atau majalah pegadaian, spanduk, brosur, dan lainlain.

b. Kantor Wilayah (KANWIL), kegiatnya mencakup kantor wilayah operasional sewilayahnya dengan media kegiatan-kegiatan yang bersifat 
wilayah. Seperti seminar, jalan sehat bersama.

c. Melalui penjualan Pribadi (personal selling), yaitu promosi yang dilakukan oleh karyawan pegadaian syariah dalam melayani, mensosialkan atau menjalankan keleihan produkproduk gadai syariah kepada nasabah yang datang langsung kepegadaian syariah.

d. Melalui publisitas (publicity), yaitu promosi dengan cara menjadi sponsor untuk kegiatan-kegiatan yang membutuhkan dana, dan membuka stand dikegiatan tersebut. Dengan menerima mahasiswa magang dan observasi juga merupakan salah satu cara mempromosikan pegadaian syariah.

e. Pihak Pegadaian Syariah melalui periklanan baik majalah, brosur, spanduk, dan media lainya melakukan berbagai upaya, agar menarik minat nasabah untuk menggunakan produk gadai syariah yang ditawarkan oleh pegadaian syariah dengan memberitahukan manfaat ataupun keuntungan yang dapat diperoleh dari produk-produk Pegadaian Syariah.

f. Promosi yang dilakukan dengan cara publisitas melalui kegiatan amal yang dilakukan, diharapkan agar masyarakat dapat melihat bahwa pegadaian syariah peduli akan masyarakat yang kurang mampu, dan peduli akan kegiatan positif yang dilakukan oleh masyarakat.

Di dalam perkembangannya

Pegadaian Syariah memiliki perkembangan yang cukup pesat dan memiliki citra yang baik dimata masyarakat karena dengan adanya Pegadaian Syariah ini dapat membantu likuiditas masyarakat ketika mereka membutuhkan uang dengan cepat maka mereka bisa datang langsung ke Pegadaian karena prosesnya sangat mudah dan cepat bila dibandingkan dengan Bank yang prosesnya membutuhkan waktu cukup lama dengan persyaratan yang lumayan sulit, selain itu juga untuk menghindari Riba agar masyarakat tidak beralih ke Rentenir karena bunganya besar.

\section{KESIMPULAN}

1. Strategi yang digunakan dalam pemasaran pembiayaan Arrum pada produk PT. Pegadaian Syariah (persero) Cabang Blauran Surabaya adalah produk, distribusi, promosi, dan harga. Keempat strategi pemasaran yang dilakukan sudah diatur dalam Pedoman Oprasional Gadai Syariah yang berlaku umum, tetapi tergantung cabang yang berbedabeda. Yang terkait dalam strategi pemasaran ini adalah dewan direksi perum pegadaian yang membuat strategi secara umum dan seluruh pegawai pegadaian syariah bertanggung jawab dalam melakkan pemasaran atas produk gadai syariah tersebut. Dan dari empat strategi tersebut yang paling berjalan adalah strategi produk dan strategi distribusi dimana Pegadaian Syariah khususnya Pegadaian Syariah yang selalu menghadirkan produk-produk baru yang sangat membantu masyarakat baik untuk keperluan sehari- hari maupun modal usaha. Sedangkan dari segi distribusi Pegadaian Syariah sudah memiliki UPC (Unit Pelayanan 
Cabang) agar mudah dijangkau oleh nasabah yang membutuhkan dana cepat untuk kebutuhan konsumtif dan produktif. Untuk mengevaluasi strategi pemasaran yang dilakukan oleh Pegadaian Syariah maka diadakan evaluasi setiap bulannya. Sehingga jika salah satu strategi ada yang tidak mengenai sasaran dan target maka strategi tersebut dirubah dan dicari strategi baru demi meningkatkan pelayanan dan meraih kepuasan konsumen. Strategi yang paling berjalan adalah strategi produk dan strategi distribusi.

2. Mekanisme pembiayaan Arrum pada PT. Pegadaian Syariah (persero) Cabang Blauran Surabaya adalah mudah dengan persyaratan yang tidak rumit, mengingat konsumennya yang sangat luas dan akses yang mudah didapat sehingga nasabah yang akan mengajukan pembiyaan tidak perlu bersusah payah. Dengan beberapa keuntungan yang lain yaitu prosesnya cepat, jangka waktu pembiayaan flexible dengan berbagai pilihan waktu dan staf pelayanan sangat ramah dan sangat membantu.

\section{Penerapan}

pembiayaan Ekonomi Syariah pada PT. Pegadaian Syariah (persero) Cabang Blauran Surabaya sudah sesuai dengan Hukum Ekonomi Syariah yang ada sebagaimana diatur dalam Fatwa Dewan Islam Nasional No. 25/DSN-MUI/III/2002 Tanggal 26 Juni 2002.

\section{DAFTAR PUSTAKA}

Ali, Zainuddin. 2008. Hukum Gadai Syariah. Jakarta: Sianar Grafika.
Burhanuddin, S. 2010. Aspek

Hukum Lembaga

Keuangan Syariah.

Yogyakarta: Graha

Ilmu.

Hutchinson, dalam Granita

Ramadhani, 2000.

Metodologi Penelitian

Hukum, Jakarta: FHUI.

Narbuko, Cholid dan Abu

Achmadi. 2005.

Metodologi Penelitian,

cet. VI, (akarta: Bumi

Aksara

Sigit, Soeharti, 1999. Pengantar

Metodologi Penelitian

Sosial, Bisnis-

Manajement, Jakarta:

Bumi Aksara.

Soekanto, Soerjono dan Sri

Mamudji. 2010.

Penelitian Hukum

Normatif, Suatu

Tinjauan Singkat,

Jakarta: Rajawali

Soekanto, Soerjono. 2001.

Penelitian Hukum

Normatif Suatu

Tinjauan Singkat,

Jakarta: Raja Grafindo

Persada.

Soemitri, Andri. 2010. Bank dan

Lembaga Keuangan

Syariah, Jakarta:

Kencana, 2010 